Keywords:

Degraded area

Indicators of quality

Native vegetation

Histórico:

Recebido 20/10/2016

Aceito 12/01/2017

Palavras chave:

Área degradada Indicadores de qualidade Vegetação nativa

Correspondência: elainenovak_@hotmail.com
Elaine Novak', Laércio Alves Carvalho', Etenaldo Felipe Santiago', Irzo Isaac Rosa Portilho'

\section{CHEMICAL AND MICROBIOLOGICAL ATTRIBUTES UNDER DIFFERENT SOIL COVER}

ABSTRACT: A challenge for the environmental recovery of degraded areas is the search for soil data. In this process, the microbiological parameters and soil chemicals are potential indicators of soil quality. This study aimed to evaluate soil quality based on microbiological and chemical soil attributes in different areas involving environmental recovery, sugarcane cultivation and remnants of native vegetation located in a rural private property farm in State of Mato Grosso do Sul, Brazil, in Hapludox Eutrophic soil. The microbiological (microbial biomass carbon, basal respiration, microbial quotient and metabolic quotient) and chemical parameters (organic matter, carbon, $\mathrm{pH}$, cationic exchange capacity, sum of bases, potassium, phosphorus, magnesium, calcium, saturation base and potential acidity) were assessed. Data were assessed by variance and multivariate analysis (Principal Component Analysis and cluster analysis). Overall, the results showed highest alteration in the chemical and microbiological characteristics of the soil in sugarcane cultivation area in comparison with other areas. Considering the studied recovery areas, RECI, REC5 and REC7 show chemical and microbiological conditions with most similarity to native vegetation. Despite the short period of the resilience enhancement of environmental recovery areas, the development of vegetation cover and establishment of the microbial community were determined to be important factors for improving soil quality and environmental recovery in several of the areas studied.

\section{ATRIBUTOS QUÍMICOS E MICROBIOLÓGICOS SOB DIFERENTES COBERTURAS DE SOLO}

RESUMO: Um desafio para a recuperação ambiental de áreas degradadas é a busca de dados de solo. Neste processo, os parâmetros microbiológicos e química do solo são potenciais indicadores de qualidade do solo. Este estudo objetivou avaliar a qualidade do solo com base em atributos microbiológicos e químicos do solo em diferentes áreas, em recuperação ambiental, cultivo de cana e remanescentes de vegetação nativa, localizada em uma fazenda de propriedade privada rural no estado de Mato Grosso do Sul, Brasil, em solo Háplico Eutrófico. Os parâmetros microbiológicos (carbono da biomassa microbiana, respiração basal, quociente microbiano e quociente metabólico) e químicos (matéria orgânica, carbono, $\mathrm{pH}$, capacidade de troca de cátions, soma de bases, potássio, fósforo, magnésio, cálcio, saturação por bases e acidez potencial) foram acessados. Dados foram avaliados por meio de análises de variância e multivariada (análise de agrupamentos e Análise de Componentes Principais). Em geral, os resultados mostraram maior alteração das características químicas e microbiológicas do solo na área de cultivo de cana em comparação com outras áreas. Considerando as áreas em recuperação estudadas, $\mathrm{RECl}$, REC5 e REC7 mostram condições químicas e microbiológicas com maior semelhança com a vegetação nativa. Apesar do curto período do realce de resiliência das áreas de recuperação ambiental, o desenvolvimento da cobertura vegetal e o estabelecimento da comunidade microbiana foram considerados fatores importantes para a melhoria da qualidade do solo e recuperação ambiental em várias das áreas estudadas.

' State University of Mato Grosso do Sul - Dourados, Mato Grosso do Sul, Brasil 


\section{INTRODUCTION}

The balance of chemical-physical properties of soils in natural ecosystems depends on the complex interactions with the biotic component. However, the removal of native vegetation and the implementation of agricultural activities, when not supported by nutrient management (CARDOSO et al., 20I I) and appropriate soil conservation practices (GOMIERO et al., 20I I), are usually associated with loss of environmental stability with consequent reduction of soil quality.

The recovery of degraded areas, of both ground and vegetation, involves a series of actions that initially seeks to minimize the effects of degradation and, subsequently implements corrective methodologies aimed at a fast recovery of the environment. However, before adopting any mitigating measures, it is of utmost importance to evaluate the soil attributes.

Soil diagnosis help to understand the degradation factors, and to define adequate methods to deal with different conditions, resulting in better planning for environmental recovery.

The success of environmental recovery programs cannot be evaluated simply by the rate of vegetation growth. Equally important are the assessment and monitoring of different chemical, physical and microbiological soil properties that are used as indicators of quality and/or environmental degradation.

Indicators of soil quality (SQI) are measurable attributes that influence the soil's ability to perform its functions. The measurement of a minimum set of indicators is required for every ecosystem (ARSHAD; MARTIN, 2002).

The analysis of chemical and microbiological attributes of soils in restoration areas is important for evaluating the performance of key functions, such as nutrient cycling and storage, decomposition of organic matter and soil stabilization. Such information on ecosystem quality indicates if the environmental conditions are suitable for plant growth and development, as well as for the maintenance of its soil biodiversity (KARLEN et al., 2003).

The main chemical attributes commonly measured are cationic exchange capacity (CEC), $\mathrm{pH}$, organic matter, carbon, potassium, nitrogen and extractable phosphorus (KARLEN et al., 2003).

Some of the microbiological soil properties are more sensitive to changes when exposed to different forms of soil management and treatment and may be considered the best indicators of soil quality (SOUZA et al., 2012). Many studies have shown that the determination of soil biomass enables a faster evaluation
(GARCÍA-ORENES et al., 2013) in comparison to chemical and physical soil attributes (FRANCHINI et al., 2007; HUNGRIA et al., 2009; KASCHUK et al., 20I0).

Overall, information on changes in microbial biomass carbon $(\mathrm{MBC})$, basal respiration $\left(\mathrm{C}-\mathrm{CO}_{2}\right)$, the metabolic quotient $\left(q \mathrm{CO}_{2}\right)$ and the microbial quotient ( $q M I C)$ may explain ecological processes of the environment. Understanding the behavior of microorganisms in the soil helps to assess land use practices that maintain or improve soil quality over time. Changes in microbial activity and the composition of soil microbial communities can directly influence fertility and plant growth (CRECCHIO et al., 2007).

Considering the influence of vegetation cover on soil dynamics, chemical and microbiological soil attributes can be efficient to identify the succession process in environmental recovery areas. For this purpose, soil attributes were estimated in three ecosystems characterized by different soil management aiming to discuss the soil quality parameters.

\section{MATERIALS AND METHODS}

The work was conducted in the municipality of Rio Brilhante, State of Mato Grosso do Sul $\left(21^{\circ} 48^{\prime} 07^{\prime \prime} \mathrm{S} / 44^{\circ} 32^{\prime} 47^{\prime \prime} \mathrm{W}\right)$. The soil is classified as Hapludox Eutrophic, and is of clayey texture. According to the Köppen classification system, the climate is humid mesothermal with hot summers and dry winters (Cwa). The study areas consisted of two sites with remnants of native vegetation, consisting of a transition zone between Brazilian Savanna (Cerrado) and Atlantic Forest, which were adopted as reference areas (identified as $\mathrm{NI}$ and N2), seven adjacent areas in environmental recovery (identified as RECI to REC7) and a sugarcane cultivation area (CN).

Environmental recovery areas were established at the same period, where originally there was a seasonal forest replaced by pasture (Brachiaria brizantha), which was used for ten years and thereafter replaced by sugarcane for two more years. Due to their location the fragments for restoration were identified as RECI REC7 and at the time of data collection the areas were approximately two years under recovery process. The soil was covered by exotic grass (Brachiaria brizantha) and some young native trees (planted during the recovery intervention and from natural regeneration) belonging to species: Trema micantha, Acrocomia aculeata, Psidium cattleianum, Peltophorum dubium, Cecropia pachystachya, Anadenanthera colubrina, Handroanthus heptaphyllus, Holocalyx balansae, Solanum paniculatum (LORENZI, 
1992, 1998, 2009), among others. In REC4 natural regeneration and planting of native tree species was performed with: Myracrodruon urundeuva, Schinus terebinthifolius, Handroanthus avellanedae, Machaerium stipitatum and Dabergia miscolobium (LORENZI, 1992, 1998, 2009), among others. In the other areas natural regeneration was applied. In all restoration areas, no mechanical intervention or fertilizer was used.

The sugarcane (RB86 - 75I5) planting was performed with conventional tillage using harrow plow, one sub soiling at a $0.45 \mathrm{~m}$ depth and a leveling harrowing. During the planting NPK fertilizer (05-15-10) was used, and during the annual cuts additional applications were done using NPK fertilizer (30-05-25) in the rows of the crop. The cultivation of sugarcane ratoon crop operations was carried out between the rows, to minimize the effects of soil compaction caused by intensive traffic of machines during the harvest. In the sampling time (rainy season 20I2), the mechanical harvesting of sugarcane culture was in the fourth cut.

To evaluate the chemical attributes of the soil, samples were collected from two layers $(0-10 \mathrm{~cm}$ and $10-20 \mathrm{~cm})$, with five random replicates for each area and layer. For evaluation of microbiological attributes of the soil (microbial biomass - MB), samples were collected at the $0-10 \mathrm{~cm}$ layer, with five replicates per random area. For both analyses the samples were collected with a Dutch auger.

The chemical analysis was performed in the laboratory following the methods described by the Brazilian Agricultural Research Corporation(EMBRAPA 1997). Based on the results of the analysis, values were estimated for calcium $\left(\mathrm{Ca}^{2+}\right)$, magnesium $\left(\mathrm{Mg}^{2+}\right)$, potassium $\left(\mathrm{K}^{+}\right)$, potential acidity $(\mathrm{H}+\mathrm{Al})$, sum of bases $(\mathrm{SB})$, base saturation ( $\mathrm{\%} \%$ ), cation exchange capacity (CEC), carbon $(\mathrm{C})$, organic matter $(\mathrm{OM})$, phosphorus $(\mathrm{P})$ and $\mathrm{pH}\left(\mathrm{CaCl}_{2}\right)$. The carbon from the soil microbial biomass $\mathrm{C}$ (MB-C) was evaluated by the fumigation-extraction method, which is based on the fact that the carbon of dead microorganisms by fumigation is released into the soil, where it can be extracted chemically according to Vance et al. (1987). The basal respiration $\left(\mathrm{C}-\mathrm{CO}_{2}\right)$ was determined by the method of fumigation-incubation proposed by Jenkinson and Powlson (1976). Following the $\mathrm{MB}-\mathrm{C}$ and $\mathrm{C}-\mathrm{CO}_{2}$ analyses, we determined the metabolic quotient $\left(q \mathrm{CO}_{2}\right)$ obtained from the ratio $\mathrm{C}-\mathrm{CO}_{2} / \mathrm{MB}-\mathrm{C}$, and the microbial quotient $(q M I C)$ obtained from the ratio MB-C/COT $x$ 100 (ANDERSON; DOMSCH, 1990).

The results of the evaluated attributes were subjected to ANOVA, with means compared by the Scott - Knott test at $5 \%$ significance. The results were also subjected to multivariate analysis (principal component analysis (PCA) and cluster analysis). PCA was performed using the package Vegan (OKSANEN et al., 2006) in the software platform $R$ ( $R$ DEVELOPMENT CORE TEAM, 2012). Data of chemical attributes in the $10-20 \mathrm{~cm}$ layer were subjected to cluster analysis, using the furthest neighbor method (complete linkage) and Euclidean distance to describe the similarity between evaluated areas.

Results are presented and discussed separately for each layer.

\section{RESULTS END DISCUSSION}

Soil chemical properties differed between the two layers in all areas studied (Table I), except for $\mathrm{P}$ content. The lowest values of $\mathrm{pH}, \mathrm{Ca}^{2+}, \mathrm{Mg}^{2+}$, sum of base (SB), base saturation (V\%), CEC, OM and $\mathrm{C}$ were measured in the sugarcane cultivation area $(\mathrm{CN})$, in both layers analyzed.

Although the lowest $\mathrm{pH}$ values were found in $\mathrm{CN}$ $(p<0.05)$, all areas had acidic soils. In areas located in the transition zone between Cerrado (Brazilian's Savanna) and Atlantic Forest, Cerrado soils predominate. These soils are naturally acidic (SILVA et al., 20I3) due to the constitution of the source material and high weathering processes or to the present vegetative and microbial population (CASTRO et al., 2008). The low $\mathrm{pH}$ values in these areas are similar to those found by Siqueira Neto et al. (2009), who studied the chemical properties of soil under different land uses in the Cerrado.

In $\mathrm{CN}$, the low $\mathrm{pH}$ values of both layers studied may also be related to the intensive use of nitrogen fertilizers, mainly as ammonium or amide, which generate $\mathrm{H}^{+}$to be nitrified in the soil (ACHIENG et al. 2010 ; YANG et al., 20I2), favoring soil acidity. The areas in environmental recovery and with remnants of native vegetation had significantly higher $\mathrm{pH}$ values due to addition of plant residues and transformation processes of OM by intense microbial activity, which can provide higher carbon accumulation in the soil surface (EFFGEN et al., 2012). An increase in $\mathrm{pH}$ is also associated with a reduction of organic anions captured by plants, leaving $\mathrm{H}^{+}$ions (PAVAN et al. 1999), which favor the formation of $\mathrm{H}$ and $\mathrm{Al}$ complexes with the compounds of plant residues, thus providing a higher amount of free $\mathrm{Ca}^{2+}$, $\mathrm{Mg}^{2+}$ and $\mathrm{K}^{+}$ions in the soil (SOUZA et al., 20I2).

Soil carbon differed according to the ecosystem studied, with higher values in the areas with remnant native vegetation and environmental recovery areas and lower values in the sugarcane cultivation area. A 33\% and $22 \%$ reduction of the carbon content in the $0-10 \mathrm{~cm}$ and $10-20 \mathrm{~cm}$ layers, respectively, were measured in $\mathrm{CN}$ and the native vegetation areas.

The highest levels of $C$ and $O M$ found in the soil of the remaining native vegetation and in the environmental recovery areas (Table I) may be related to constant 
TABLE I Means of $\mathrm{pH}$, organic matter $(\mathrm{OM})$, carbon $(\mathrm{C})$, phosphorus $(\mathrm{P})$, exchangeable cations $(\mathrm{K}+, \mathrm{Ca} 2+$ and $\mathrm{Mg} 2+)$, potential acidity $(\mathrm{H}+\mathrm{Al})$, sum of bases $(\mathrm{SB})$, cation exchange capacity $(\mathrm{CEC})$ and base saturation $(\mathrm{V} \%)$ for the $0-10$ $\mathrm{cm}$ and $10-20 \mathrm{~cm}$ layer in areas of environmental recovery, native vegetation and sugarcane cultivation.

\begin{tabular}{|c|c|c|c|c|c|c|c|c|c|c|c|}
\hline Areas & $\mathrm{pH}$ & OM & C & $\mathrm{P}$ & $\mathrm{K}$ & $\mathrm{Ca}$ & $\mathrm{Mg}$ & $\mathrm{H}+\mathrm{Al}$ & SB & CEC & $\mathrm{V}$ \\
\hline & $\left(\mathrm{CaCl}_{2}\right)$ & ---------g.d & $n^{-3}---\cdots----$ & $\left(\mathrm{mg} \cdot \mathrm{dm}^{-3}\right)$ & & ------- & $\mathrm{cm}$ & $\mathrm{dc} \cdot \mathrm{dm}^{-3}$ & - & & (\%) \\
\hline \multicolumn{12}{|c|}{ Layer $0-10 \mathrm{~cm}$} \\
\hline REC I & $5.60 \mathrm{~b}$ & $49.18 \mathrm{~b}$ & $28.59 \mathrm{~b}$ & $2.25 \mathrm{a}$ & $0.18 b$ & $15.08 \mathrm{a}$ & $3.74 \mathrm{~b}$ & $4.49 \mathrm{a}$ & $19.00 \mathrm{a}$ & $23.49 \mathrm{a}$ & $80.76 \mathrm{a}$ \\
\hline REC 2 & $5.46 \mathrm{~b}$ & $49.78 \mathrm{~b}$ & $28.94 \mathrm{~b}$ & $3.03 \mathrm{a}$ & $0.46 \mathrm{a}$ & $12.03 \mathrm{~b}$ & $3.49 \mathrm{~b}$ & $4.66 \mathrm{a}$ & I5.98 b & $20.84 \mathrm{ab}$ & $76.5 \mathrm{I} \mathrm{b}$ \\
\hline REC 3 & $5.50 \mathrm{~b}$ & $44.70 \mathrm{~b}$ & $25.98 \mathrm{c}$ & $1.40 \mathrm{a}$ & $0.12 \mathrm{~b}$ & $11.12 \mathrm{~b}$ & $3.63 \mathrm{~b}$ & $4.63 \mathrm{a}$ & $14.88 \mathrm{~b}$ & $19.5 \mid \mathrm{b}$ & $76.23 \mathrm{~b}$ \\
\hline REC 4 & $5.60 \mathrm{~b}$ & $44.80 \mathrm{~b}$ & $26.04 c$ & $2.29 \mathrm{a}$ & $0.28 \mathrm{~b}$ & $11.31 \mathrm{~b}$ & $3.06 \mathrm{~b}$ & $4.49 \mathrm{a}$ & $14.66 \mathrm{~b}$ & 19.16 b & $76.58 \mathrm{~b}$ \\
\hline REC 5 & $5.48 \mathrm{~b}$ & $55.91 \mathrm{a}$ & $32.5 \mathrm{I} \mathrm{a}$ & $1.46 \mathrm{a}$ & $0.52 \mathrm{a}$ & $11.76 \mathrm{~b}$ & $3.97 \mathrm{a}$ & $4.88 \mathrm{a}$ & $16.26 \mathrm{~b}$ & $21.15 a b$ & $76.59 \mathrm{~b}$ \\
\hline REC 6 & $5.40 \mathrm{~b}$ & $42.80 \mathrm{c}$ & $24.88 c$ & $0.95 \mathrm{a}$ & $0.27 \mathrm{~b}$ & $9.21 \mathrm{c}$ & $3.47 \mathrm{~b}$ & $4.68 \mathrm{a}$ & $13.07 \mathrm{c}$ & $17.75 \mathrm{c}$ & $73.60 \mathrm{~b}$ \\
\hline REC 7 & $5.86 \mathrm{a}$ & $50.23 \mathrm{~b}$ & $29.20 \mathrm{~b}$ & $1.34 \mathrm{a}$ & $0.35 \mathrm{~b}$ & $11.15 \mathrm{~b}$ & $3.8 \mathrm{Ib}$ & $3.64 \mathrm{~b}$ & $\mathrm{I} 5.32 \mathrm{~b}$ & $18.96 \mathrm{~b}$ & $80.75 \mathrm{a}$ \\
\hline $\mathrm{CN}$ & $5.00 \mathrm{c}$ & $34.47 \mathrm{~d}$ & $20.04 d$ & $2.03 \mathrm{a}$ & $0.23 \mathrm{~b}$ & $6.69 \mathrm{~d}$ & $1.80 \mathrm{c}$ & $5.40 \mathrm{a}$ & $8.72 \mathrm{~d}$ & $14.13 \mathrm{~d}$ & $61.84 \mathrm{c}$ \\
\hline NI & $5.50 \mathrm{~b}$ & $51.88 \mathrm{~b}$ & $30.16 \mathrm{~b}$ & $1.40 \mathrm{a}$ & $0.7 \mathrm{I} a$ & $10.55 \mathrm{~b}$ & $5.11 \mathrm{a}$ & $4.86 \mathrm{a}$ & $16.38 \mathrm{~b}$ & $21.24 \mathrm{ab}$ & $76.03 \mathrm{~b}$ \\
\hline N2 & $6.06 \mathrm{a}$ & $50.13 \mathrm{~b}$ & $29.14 b$ & $1.15 \mathrm{a}$ & $0.77 \mathrm{a}$ & $13.69 \mathrm{a}$ & $3.78 \mathrm{~b}$ & $3.20 \mathrm{~b}$ & $18.25 \mathrm{a}$ & $21.46 \mathrm{ab}$ & $85.06 \mathrm{a}$ \\
\hline \multicolumn{12}{|c|}{ Layer $10-20 \mathrm{~cm}$} \\
\hline REC I & $5.42 \mathrm{~b}$ & $42.80 \mathrm{a}$ & $24.88 \mathrm{a}$ & $3.17 \mathrm{a}$ & $0.12 \mathrm{~b}$ & $13.33 \mathrm{a}$ & $2.84 \mathrm{~b}$ & $4.80 \mathrm{~b}$ & $16.30 \mathrm{a}$ & $21.11 \mathrm{a}$ & $77.15 \mathrm{a}$ \\
\hline REC 2 & $5.36 \mathrm{~b}$ & $43.20 \mathrm{a}$ & $25.11 \mathrm{a}$ & $1.32 \mathrm{a}$ & $0.24 \mathrm{~b}$ & $10.05 \mathrm{~b}$ & $2.72 \mathrm{~b}$ & $4.94 \mathrm{~b}$ & I3.02 b & $17.97 \mathrm{a}$ & $72.21 \mathrm{a}$ \\
\hline REC 3 & $5.48 \mathrm{~b}$ & $40.6 \mathrm{I} \mathrm{b}$ & $23.6 \mathrm{I} \mathrm{b}$ & $1.12 \mathrm{a}$ & $0.10 \mathrm{~b}$ & $11.16 \mathrm{~b}$ & $3.06 \mathrm{a}$ & $4.71 \mathrm{~b}$ & $14.33 \mathrm{a}$ & $19.04 \mathrm{a}$ & $75.07 \mathrm{a}$ \\
\hline REC 4 & $5.48 \mathrm{~b}$ & $40.86 \mathrm{~b}$ & $23.75 \mathrm{~b}$ & $1.30 \mathrm{a}$ & $0.19 \mathrm{~b}$ & $10.61 \mathrm{~b}$ & $2.63 \mathrm{~b}$ & $4.77 \mathrm{~b}$ & $13.44 \mathrm{~b}$ & $18.22 \mathrm{a}$ & $73.82 \mathrm{a}$ \\
\hline REC 5 & $5.48 \mathrm{~b}$ & $48.83 \mathrm{a}$ & $28.39 a$ & $1.16 \mathrm{a}$ & $0.32 \mathrm{~b}$ & $11.16 \mathrm{~b}$ & $3.51 \mathrm{a}$ & $4.65 \mathrm{~b}$ & $15.02 \mathrm{a}$ & $19.67 \mathrm{a}$ & $75.96 \mathrm{a}$ \\
\hline REC 6 & $5.34 \mathrm{~b}$ & $40.01 \mathrm{~b}$ & $23.26 \mathrm{~b}$ & $0.73 \mathrm{a}$ & $0.20 \mathrm{~b}$ & $9.47 \mathrm{~b}$ & $3.32 \mathrm{a}$ & $4.75 \mathrm{~b}$ & $12.99 \mathrm{~b}$ & $17.74 \mathrm{a}$ & $73.03 \mathrm{a}$ \\
\hline REC 7 & $5.80 \mathrm{a}$ & $44.40 \mathrm{a}$ & $25.8 \mathrm{I} \mathrm{a}$ & $0.94 \mathrm{a}$ & $0.25 \mathrm{~b}$ & $10.73 \mathrm{~b}$ & $3.57 \mathrm{a}$ & $3.86 \mathrm{c}$ & $14.56 \mathrm{a}$ & $18.43 \mathrm{a}$ & $78.99 \mathrm{a}$ \\
\hline $\mathrm{CN}$ & $5.14 \mathrm{c}$ & $34.17 c$ & $19.87 \mathrm{c}$ & $1.99 \mathrm{a}$ & $0.19 \mathrm{~b}$ & $6.75 \mathrm{c}$ & $1.80 \mathrm{c}$ & $5.11 \mathrm{~b}$ & $8.75 \mathrm{c}$ & 13.86 b & $63.23 \mathrm{~b}$ \\
\hline NI & $5.00 \mathrm{c}$ & $44.15 \mathrm{a}$ & $25.67 \mathrm{a}$ & $0.98 \mathrm{a}$ & $0.6 \mathrm{I} \mathrm{a}$ & $7.79 c$ & $3.94 \mathrm{a}$ & $6.72 \mathrm{a}$ & $12.34 \mathrm{~b}$ & $19.06 \mathrm{a}$ & $63.44 \mathrm{~b}$ \\
\hline N2 & $5.98 \mathrm{a}$ & $43.42 \mathrm{a}$ & $25.26 \mathrm{a}$ & $1.96 \mathrm{a}$ & $0.72 \mathrm{a}$ & $11.30 \mathrm{~b}$ & $3.40 \mathrm{a}$ & $3.44 \mathrm{c}$ & $15.43 \mathrm{a}$ & $18.87 \mathrm{a}$ & $81.67 \mathrm{a}$ \\
\hline $\mathrm{CV}$ & 5.13 & 8.60 & 8.60 & 85.38 & 80.59 & 14.49 & 15.35 & 16.93 & 13.76 & 7.99 & 6.83 \\
\hline
\end{tabular}

Means followed by the same letter and number in columns do not differ statistically (Scott - Knott test, $5 \%$ significance). RECI (environmental recovery area I), REC2 (environmental recovery area 2), REC3 (environmental recovery area 3), REC4 (environmental recovery area 4), REC5 (environmental recovery area 5), REC6 (environmental recovery area 6), REC7 (environmental recovery area 7), CN (sugarcane cultivation area), NI (native vegetation I) and N2 (native vegetation 2).

deposition of plant residues and decreased disturbance in these areas, compared to the sugarcane cultivation area $(\mathrm{CN})$. In the areas of environmental recovery, the predominance of pioneer species with relatively short life cycles may have contributed to the continuous addition of organic residues in the soil. In addition, the high amount of organic matter found at REC5 may also be related to the deposit of vegetable residues (litterfall), favored by its geographical position, which tends to have considerable ecotone.

The low carbon found in $\mathrm{CN}$ is likely related to low litterfall disposal (data not shown) and the higher respiration rate $\left(q \mathrm{CO}_{2}\right)$ of soil organisms, thus leading to low SOM levels and an increased loss by erosion or mineralization (PAVAN et al., 1999). This result agrees with Houghton et al. (199I), who claim that there is a decline in the stock of organic matter following the conversion of native forests into agricultural systems.
According to these authors, this reduction can be attributed to increased soil erosion, the more accelerated processes of mineralization of soil organic matter and minor amounts of organic inputs in grazed systems compared to the native forests, where the permanence of residues in the soil provides aggregation that protect it from mineralization, thus promoting the increase of soil OM (SÁ et al., 200I).

The highest OM found under native vegetation is in general, associated to litterfall that accumulate specially under vegetal cover. The OM levels are also influenced by the soil physical-chemical characteristics, such as soil structure, moisture holding capacity, diversity and activity of soil organisms and nutrient availability (FAO, 2005).On the other hand, different levels of $\mathrm{OM}$ are found according to the phytophysiognomy, for example, soils under rainforest (Atlantic rainforest), seasonal forests (Semi-deciduous Mesophytic Forest, 
Deciduous Seasonal Forest and Riparian Forest), have higher OM levels than savanna's grassy or woodlands soils (SKORUPA et al., 20I2).

The replacement of native vegetation in the sugarcane cultivation area and in areas of environmental recovery did not promote significant changes in the levels of available phosphorus. This was also observed by Cardoso et al. (20I I) in an area of grazing land converted from woody vegetation; by Liu et al. (2002) who studied the effect of natural forest, grassland, shrub, secondary forest as forest on soil properties; and by Silva et al. (2009) who studied the attributes of a Cerrado Oxisol planted with forest species. According to Gama-Rodrigues et al. (2008a), the non-variability of $P$ available in soils under different types of vegetation is associated with the robust stabilization of this element in highly weathered soils.

On the other hand, exchangeable $\mathrm{Ca}^{2+}$ and $\mathrm{Mg}^{2+}$, soil organic matter (SOM), sum of bases (SB) and cation exchange capacity (CEC) were significantly reduced by the conversion of native vegetation in the sugarcane cultivation area. The lower levels of $\mathrm{Ca}^{2+}$ observed in the 10-20 cm layer of CN and NI are probably related to the immobilization of this element in the aero-biomass of the plant (SIQUEIRA NETO et al., 2009).

The highest levels of CEC were found in the soil under native vegetation (NI, N2) and in areas of environmental recovery (RECI, REC2 and REC5), when compared to the sugarcane cultivation area. However, the higher content of CEC in $\mathrm{NI}(10-20 \mathrm{~cm})$ is directly related to its high potential acidity $\left(6.72 \mathrm{cmol}_{\mathrm{c}} \mathrm{dm}^{-3}\right)$. This results in low soil fertility due to the effects of aluminum in its exchangeable form on the nutrient absorption by plants. The removal of native vegetation cover for agricultural purposes led to a decrease in soil CEC in both layers studied, which can be attributed to changes in the levels of organic matter and soil exchangeable cations, as confirmed by Souza et al. (2012).

The high potential acidity, except in REC7 and N2, may be related to the dissociation of $\mathrm{H}^{+}$of phenolic and carboxylic groups of organic matter, the leading suppliers of protons to the soil (EVANS et al., 20I2). High potential acidity in $\mathrm{NI}$ could also be related to low levels of $\mathrm{Ca}^{2+}$. Similar values of potential acidity in a soil under native vegetation were reported by Carvalho et al. (2007) in a Cerrado Oxisol after conversion to agricultural land, and by Carneiro et al. (2009) in a study of soil properties under different systems of land uses and management of the Cerrado.

Values of base saturation in the sugarcane cultivation area were low, because the crop rapidly extracts nutrients (especially basic cations) from the soil for its development. However, despite smaller V\% values in both layers, they were still in the range considered ideal for cultivation (> 50\%) (Cherubina et al. 2015) which was also true for the other areas studied. The low V\% observed in the soil of $\mathrm{NI}(10-20 \mathrm{~cm}$ layer) probably is due to the high content of $\mathrm{H}+\mathrm{Al}$ and low basic cations.

Microorganisms represent the richest repertoire in chemistry and molecular diversity in nature, providing the basis for ecological processes such as biogeochemical cycles (PANIZZON et al., 20I5) and are fundamental for soil quality because they can alter the physico-chemical characteristics of the environment, directly participating in the transformations of nitrogen and phosphorus (MASSENSSINI et al., 20I4).

The microbial biomass $(\mathrm{MB})$ is considered the most active part of the soil organic matter (HAYNES, 2008; SINGH et al., 20II) and generally comprises $2-4 \%$ of total organic carbon (GAMA-RODRIGUES, 1999). Here, lower values indicate carbon losses from the system. The MB-C content of the soil ranged from $591.54 \mu \mathrm{g} \mathrm{C} \mathrm{g-1}$ to $133.67 \mu \mathrm{g} \cdot \mathrm{C} \cdot \mathrm{g}^{-1}$ in native forests and sugarcane, respectively (Table 2 ).

The replacement of native vegetation by sugarcane cultivation resulted in a reduction of $\mathrm{MB}-\mathrm{C}$ by $77.4 \%$. However, converting sugarcane areas into areas of environmental recovery promoted an increase of MB-C (5I.09\%, 53.69\%, 60.98\%, 59.04\%, 64.19\%, 69.17\%

TABLE 2 Means of carbon microbial biomass of soil (MB$\mathrm{C})$, basal respiration $\left(\mathrm{C}-\mathrm{CO}_{2}\right)$, metabolic quotient $\left(\mathrm{qCO}_{2}\right)$ and microbial quotient $(\mathrm{qMIC})$ in the $0-10$ $\mathrm{cm}$ layer measured in the areas of environmental recovery, native vegetation and sugarcane cultivation.

\begin{tabular}{|c|c|c|c|c|}
\hline & MB-C & $\mathrm{C}-\mathrm{CO}_{2}$ & $\mathrm{qCO}_{2}$ & qMIC \\
\hline Area & $\mu \mathrm{g} \cdot \mathrm{C} \cdot \mathrm{g}^{-1}$ & $\begin{array}{l}\mu \mathrm{g} \cdot \mathrm{C}-\mathrm{CO}_{2} \mathrm{~g}^{-1} \quad \mu \\
\text { soil dry }\end{array}$ & $\begin{array}{l}\mathrm{C}-\mathrm{CO}_{2} \mu \mathrm{g} \\
\mathrm{MB}-\mathrm{Ch}^{-1}\end{array}$ & $\%$ \\
\hline REC I & $273.3 \mathrm{~b}$ & $24.0 \mathrm{~b}$ & $40.9 \mathrm{~b}$ & $0.7 \mathrm{~b}$ \\
\hline REC 2 & $288.7 \mathrm{~b}$ & $29.3 \mathrm{~b}$ & $42.9 \mathrm{~b}$ & $0.8 \mathrm{~b}$ \\
\hline REC 3 & $342.6 \mathrm{~b}$ & $30.3 \mathrm{~b}$ & $38.5 \mathrm{~b}$ & $0.9 \mathrm{~b}$ \\
\hline REC 4 & $326.4 \mathrm{~b}$ & $26.4 \mathrm{~b}$ & $33.6 \mathrm{~b}$ & $0.9 \mathrm{~b}$ \\
\hline REC 5 & $373.3 \mathrm{~b}$ & $27.7 \mathrm{~b}$ & $31.2 \mathrm{~b}$ & $I . I \mathrm{a}$ \\
\hline REC 6 & $433.7 \mathrm{a}$ & $31.2 \mathrm{~b}$ & $30.0 \mathrm{~b}$ & $1.2 \mathrm{a}$ \\
\hline REC 7 & $286.8 \mathrm{~b}$ & $27.2 b$ & $40.1 \mathrm{~b}$ & $I . I \mathrm{a}$ \\
\hline $\mathrm{CN}$ & I33.7 c & $22.5 \mathrm{~b}$ & $141.9 \mathrm{a}$ & $0.5 \mathrm{~b}$ \\
\hline N I & $504.9 \mathrm{a}$ & $35.6 \mathrm{a}$ & $30.2 \mathrm{~b}$ & $1.0 \mathrm{a}$ \\
\hline N 2 & $591.5 \mathrm{a}$ & $40.4 \mathrm{a}$ & $31.8 \mathrm{~b}$ & $1.2 \mathrm{a}$ \\
\hline $\mathrm{CV}$ & 30.48 & 26.54 & 52.29 & 32.03 \\
\hline
\end{tabular}

Means followed by the same letter and number do not differ statistically (Scott - Knott test, 5\% significance). REC (environmental recovery area) 1-7, CN (sugarcane), N (native vegetation) I-2. 
and $50.00 \%$, in RECI, REC2, REC3, REC4, REC5, REC6 and REC7, respectively). This indicates that the disruption of agricultural production leads to a reduction of MB-C, gradually enhancing the environmental recovery process, suggesting that the bacterial community can be restored after agricultural use of the soils is abandoned. Studies with chronosequences of forest to pasture areas in the Amazonia region have shown that the microbial biomass reduced in the soil after three years of establishment of pastures (CENCIANI et al., 20II) and change in the composition of the microbial community (LAMMEL et al., 2015). Similar results were also observed by Silva et al. (2009) who reported that MB-C under managed forest was about half of that found under Cerrado.

Changes in $\mathrm{MB}$ are connected to components of the vegetation, in particular diversity. The richness and abundance of native tree species imply a continuous deposition of organic substrates with varying composition in the litter, promoting higher levels of microbial biomass (SOUZA et al., 20I2) as observed in the soil under native vegetation (CUNHA et al., 20I2).

Microbiological attributes recorded in our study corroborate the findings of Susyan et al. (20II). Studying forest succession on abandoned arable land in Russia, they found that soil microbial biomass increased during successive vegetation periods, possibly due to increased inflow and accumulation of organic carbon in the soil. The increase in soil microbial biomass under a growing vegetation cover may be related to the intrinsic properties of the cultivation, as well as to organic substances produced by the roots (BELO et al., 20I2).

Our results suggest environmental improvement due to the development of soil microorganisms: higher microbial $C$ values lead to greater temporary immobilization of nutrients and, consequently to reduced nutrient loss. Cultivation systems generally have lower levels of MB-C than soils under native vegetation (KASCHUK et al., 20I0). The low level of MB-C under sugarcane cultivation may also be related the disruption of microbial communities by certain management forms: I) nitrogen fertilization; 2) allocation of decomposed waste (FRAZÃO et al., 20l0); 3) traditional burning of sugarcane crop, a factor associated with strong alteration in the structure of soil community (RACHID et al., 2013); 4 ) the quantity and quality of crop residues available to soil microorganisms (GAMA-RODRIGUES et al., 2008b).

Higher values of basal respiration (release of $\mathrm{C}-\mathrm{CO}_{2}$ ) occur with greater biological activity, which is directly related to the availability of soil $\mathrm{C}$ and/or microbial biomass (ALLEN et al., 20II). Thus, a high respiration rate can be interpreted as a desirable feature, considering that the decomposition of organic waste will provide nutrients for plants (SCHLOTER et al., 2003; ROSCOE et al., 2006). Our results indicate that there are significant differences between the areas of native vegetation, environmental recovery and of sugarcane cultivation (Table 2). The greater release of $\mathrm{CO}_{2}$ in native vegetation areas compared to environmental recovery areas may be related to the constant and greater incorporation of residues, which promotes an increase in biomass and soil microbial activity in climax communities or secondary successional stages rather than at the beginning of succession (JIANG et al., 2009). The high plant diversity in these areas also favors higher diversity of specific combinations of arbuscular mycorrhizal fungi (König et al. 20l0) as well as bacterial communities (NAZIR et al., 20I0) and changes in physical and chemical soil attributes responding to changes in the community structure of soil organisms (RACHID et al., 20I2).

The lowest level of $\mathrm{CO}_{2}$ recorded in the soil of $\mathrm{CN}$ may be related to the presence of inhibitory substances in the soil, nutritional factors (Singh et al. 20 I I), soil tillage, the application of pesticides and chemical fertilizers and the resulting increase in biological activity and carbon oxidation (RACHID et al., 20I2).

Our results agree with Silva et al. (2012), Jiang et al. (2009) and Susyan et al. (201 I), who found higher values of basal respiration in soil under native vegetation.

The analysis of the values of the metabolic quotient or the specific rate of respiration $\left(q \mathrm{CO}_{2}\right)$ representing the amount of $\mathrm{C}-\mathrm{CO}_{2}$ released per unit of microbial biomass in a given time revealed a higher consumption of $C$ by the microbial community of the sugarcane area, with the lowest values of the metabolic quotient observed in the native vegetation areas and in areas of environmental recovery (Table 2 ). These results indicate a reduced $\mathrm{CO}_{2}$ loss per unit of biomass (LOURENTE et al., 20I I) and therefore a greater, near steady-state stability of the system (INSAM; DOMSCH, 1988).

The higher values $q \mathrm{CO}_{2}$ in $\mathrm{CN}$ may be related to the modified soil structure by the applied management system. High $q \mathrm{CO}_{2}$ values can suggest an imbalance of the microbial community, changes in the metabolism of the organisms and ecosystems subjected to stress conditions or disorder (ANDERSON; DOMSCH, 1993; SANTOS et al., 20I5), considering that under unfavorable conditions, the organisms require more energy (SCHIMEL et al., 2007) resulting in higher losses of $\mathrm{CO}_{2}$ and lower incorporation of $\mathrm{C}$ in the tissue (ANDERSON; DOMSCH, 1993). The $q \mathrm{CO}_{2}$ values of other evaluated areas did not 
differ significantly, indicating that SOM is stabilized. The response of $\mathrm{qCO}_{2}$ in the soil is unpredictable, values can increase or reduce stress as indicated (soil availability of $\mathrm{C}$, increasing the $\mathrm{pH}$, clay content and quantity of microbial biomass) (WARDLE; GHANI, 1995).

The microbial biomass in the soil is more efficient when the loss of $\mathrm{C}$ as $\mathrm{CO}_{2}$ is smaller by respiration and a significant fraction of $\mathrm{C}$ is incorporated into microbial tissue (ROSCOE et al., 2006). High values indicate that microbial activity converts organic carbon less efficiently into soil microbial biomass (WARDLE; GHANI, 1995). Thus, in areas previously disturbed by intense agricultural activity and no longer used, soil $\mathrm{qCO}_{2}$ levels decrease, indicating that the ecosystem tends towards stability during successional stages.

The microbial quotient ( $q M I C)$ was highest in soils under native vegetation and some of the recovery areas (REC5, REC6 and REC7), varying from $1.05 \%$ to $1.21 \%$. The lowest values were found in soils with sugarcane cultivation and various recovery areas (RECI, REC2, REC3 and REC4). The low qMIC values of some environmental recovery areas may be related to a reduced availability of nutrients that support microbial biomass, the inhibition of soil microorganisms by excessive acidity or toxicity of $\mathrm{Al}^{3+}$, or to other factors such as the degree of stabilization of organic carbon and historic soil management (CUNHA et al., 20I2).

When microbial biomass is under stress, its ability to convert organic $\mathrm{C}$ to microbial biomass is reduced, resulting in a reduced $q M I C$ level. In contrast, higher values of $q M I C$ indicate more appropriate conditions for microbial growth, facilitated by the addition of organic matter of good quality and the elimination of the limiting factor (SOUZA et al., 20I5).

Data on soil microbial biomass, organism's activity and chemical characteristics of the soil can be best understood when discussed with the aid of integrated tools such as principal component analysis (PCA). The sum of the retained principal components of PCA explained $77.42 \%$ of the original variability in the data and was related to the effects of different areas on chemical and microbiological soil attributes. The retained components $\mathrm{PCl}$ and $\mathrm{PC2}$ explained $62.45 \%$ and $15.89 \%$ of the variation, respectively. Chemical and microbiological soil attributes were related to the different areas studied (Figure I).

Microbiological ( $q \mathrm{MIC}, \mathrm{MB}-\mathrm{C}$ and $\mathrm{C}-\mathrm{CO}_{2}$ ) and chemical ( $\mathrm{Mg}$ and $\mathrm{K}$ ) attributes were positively related to areas with remnant native vegetation ( $\mathrm{NI}$ and $\mathrm{N} 2$ ) and REC7. The areas of environmental recovery $\mathrm{RECI}$ and REC5 formed a group with the chemical attributes $\mathrm{Ca}$,
CEC, SB, MO, C, V\%, while the presence of $P$ and $H$ $+\mathrm{Al}$ was associated to the areas of REC2 and REC4. These results suggest that a greater set and diversity of factors (flora, fungal hyphae and litter on the soil surface) in natural ecosystems favor the maintenance of chemical and microbiological attributes of the soil (ALVES et al., $20 \mathrm{II}$ ), especially in the native vegetation areas or RECs with native species.

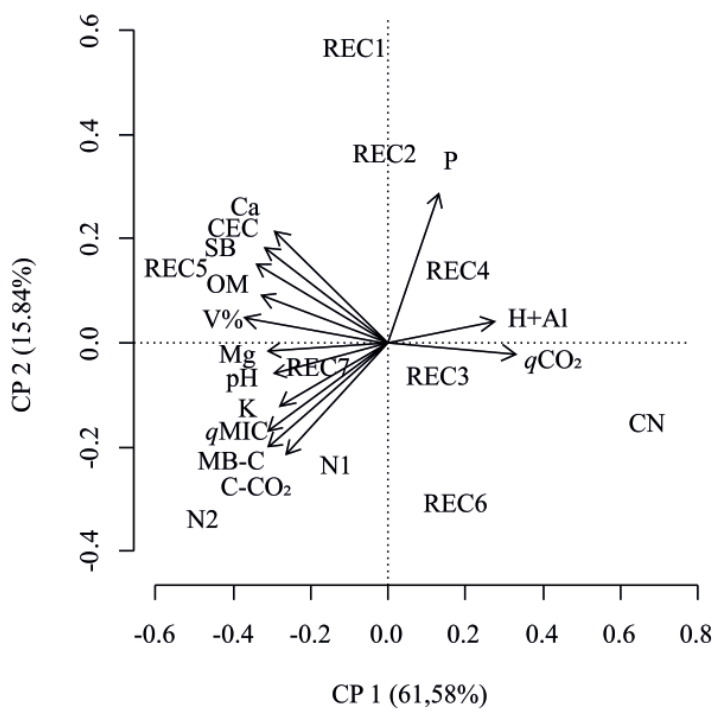

FIGURE I Biplot of chemical and microbiological soil attributes $(0.00-0.10 \mathrm{~m})$ of the studied areas. $\mathrm{PCl}$ and $\mathrm{PC} 2$ $=$ principal components $\mathrm{I}$ and 2, respectively. RECI- REC7 = environmental recovery areas I-7, $\mathrm{CN}$ = sugarcane cultivation area; $\mathrm{NI}$ and $\mathrm{N} 2=$ remnants of native vegetation.

Of all recovery areas, RECI, REC5 and REC7 stand out for their superior quality according to the soil attributes studied here. Residues on the soil supported an increased activity of heterotrophic microorganisms, since higher values of $\mathrm{C}-\mathrm{CO}_{2}$ imply higher biological activity of microorganisms, which are closely related to MB-C levels (KUZYAKOV et al., 20I0). CN, REC3 and REC6 were positively related to the $\mathrm{qCO}_{2}$ (Figure I), indicating a loss of $\mathrm{C}$ as $\mathrm{CO}_{2}$.

The hierarchical grouping analysis to the chemical attributes studied allowed to separate interpretative groups (Figure 2), in which environmental recovery areas, sugar cane cultivation and native vegetation were grouped according to their similarity degree, separated at a Euclidean distance of $100 \%$, indicating that the similarity between them was approximately $0 \%$.

GI contained the subgroups "level I" with $\mathrm{NI}$, N2 and "level 2" with REC5, RECI and REC7, which were separated by a Euclidean distance greater than $40 \%$, implying that the similarity between them is 


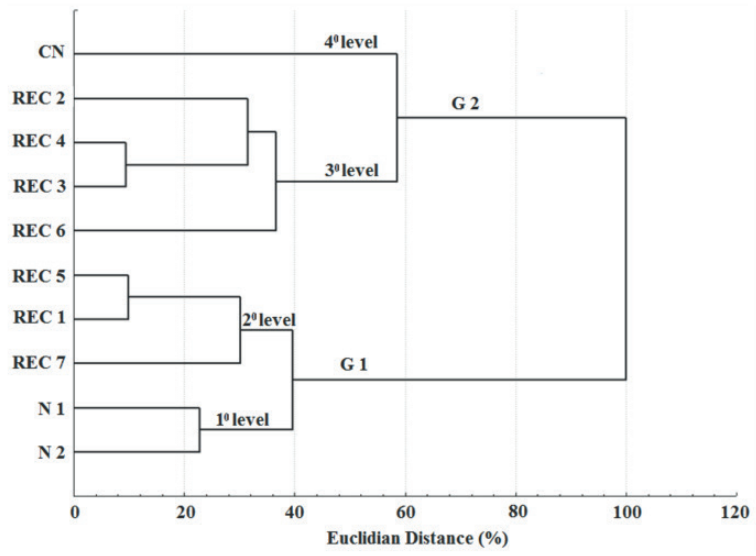

FIGURE 2 Dendrogram of distances of soil chemical attributes (0.10- $0.20 \mathrm{~m}$ ) in the studied areas. RECI - REC7 = environmental recovery areas I-7; $\mathrm{CN}=$ sugarcane cultivation area; $\mathrm{NI}$ and $\mathrm{N} 2=$ remnants of native vegetation.

approximately $60 \%$. GI included the areas that were characterized by better recovery of soil chemical attributes. The similarity of recovery areas included in this group (REC I, 5 and 7) and of areas with remaining native vegetation (NI, N2) was over $50 \%$. The balance of soil chemical attributes may be favored in natural systems where plant diversity is maintained and the soil remains undisturbed.

G2 contained the subgroups "level 3 " with REC2, REC3, REC4, REC6 and "level 4" with CN, which were separated by a Euclidean distance of less than $58 \%$, indicating a similarity of approximately $42 \%$ between these two subgroups (Figure 2). This suggests that the areas contained in this group require more time for the recovery of chemical attributes in the deeper layers, and were therefore more similar to the sugarcane area $(\mathrm{CN})$. Soil tilling can interfere directly with the physical, chemical and microbiological processes of this complex (GODOY et al., 2013; STEFANOSKI et al., 2016), reducing the maintenance of microbiota and affecting the uptake of nutrients by plants (LISBOA et al., 2013; CHEN et al., 20l4).

In general terms, the groups observed (that represent different soil management), suggests that sugar cane management induces changes on soil attributes distinct from native vegetation cover. These are related to several factors, with emphasis to the variability between crop and natural vegetation fertility and the management practices (RUIZ et al., 20I5), chemical soil balance from crop fertilization, different root exudates from crop and native trees roots (BADRI; VIVANCO, 2009; BOWSHER et al., 2016) and mineral cycling associated to microbiological activity (SU et al., 20I5).
The isolated attributes and multivariate analyses both showed the link between studied areas and the soil changes when applied a specific management. Considering native vegetation, an equilibrated environment, we find similarity to some attributes with RECs, thus the vegetal diversity enhancement promoted by restauration or natural regeneration is associated to increase of vegetal waste deposition with diverse composition. Similar results are proposed by Polo et al. (2015) evaluating the effects of organic matter pulse on soil composition.

Therefore, it is expected that in the long run the recovering areas will reach their levels of stability, sustainability and biological integrity, restoring the ecological processes common to forest or healthy ecosystems.

\section{CONCLUSION}

Our results provide information about the influence of vegetation cover on soil quality properties in a transition region between the Cerrado and the Atlantic Forest. The chemical variables were efficient to indicate soil characteristics changes over the succession when native vegetation, recovery area and agricultural systems were compared.

In the environmental recovery areas studied, although the time to the resilience increment was relatively short ( 2 years), the type of ecosystem, development and distinct soil management practices were important factors for improving soil quality and protection.

\section{REFERENCES}

ACHIENG, J. O.; OUMA, G.; ODHIAMBO, G;MUYEKHO, F. Effect of farmyard manure and inorganic fertilizers on maize production on Alfisols and Ultisols in Kakamega, western Kenya. Agriculture and Biology Journal of North America, v. I, n.4, p. 430-439, 2010.

ALLEN, D.E.; SINGH, B.P.; DALAL, R.C. Soil health indicators, soil health and climate change. A review of current knowledge. In B.P. Singh et al. (eds.). Soil Health and Climate Change, Soil Biol., 29, p 25-45, 20 I I.

ALVES, T. S.; CAMPOS, L. L.; NICOLAU, E. N.; MATSUOKA, M.; LOUREIRO, M. F. Biomassa e atividade microbiana de solo sob vegetação nativa e diferentes sistemas de manejo. Acta Scientiarum Agronomy, v. 33, n. 2, 34I-347., 20 I I.

ANDERSON, T.H.; DOMSCH, K.H. Application of ecophysiological quotients ( $\mathrm{qCO} 2$ and $\mathrm{qD}$ ) on microbial biomasses from soils of different cropping histories. Soil Biology and Biochemistry, v.22, n.2, p. 25 I-255, 1990.

ANDERSON, T.H.; DOMSCH, K.H. The metabolic quotient for $\mathrm{CO}_{2}\left(\mathrm{qCO}_{2}\right)$ as a specific activity parameter to assess the effects of environmental conditions, such as $\mathrm{pH}$, on the microbial biomass of forest soils. Soil Biology and Biochemistry, v.25, n.3, p. 393-395, 1993. 
ARSHAD, M.A.; MARTIN, S. Identifying critical limits for soil quality indicators in agro-ecosystems. Agriculture, Ecosystems \& Environment., v.88, n.2, p. I53-160, 2002.

BELO, E.S.; TERRA, F.D.; ROTTA, L.R.; VILELA, L.A.; PAULINO, H.B.; SOUSA, E.D.; VILELA, L.A.F; CARNEIRO, M.A.C. Decomposição de diferentes resíduos orgânicos e efeito na atividade microbiana em um Latossolo Vermelho no Cerrado. Global Science and Technology, v.5, n.3, p. I07-I I6, 2012.

BADRI, D.V.; VIVANCO, J.M. Regulation and function of roof exudates. Plant, Cell and Environment, v.32, n.6, p. 66668I, 2009.

BOWSHER, A.W.; ALI, R.; HARDING, S.A.; TSAI, C.J.; DONOVAN, L.A. Evolutionary divergences in root exudate composition among ecologically- contrasting Helianthus species. Plos one, v.II, n. I, p. I-I6, 2016.

CARDOSO, E.L.; SILVA, M.L.N.; CURI, N.; FERREIRA, M.M.; FREITAS, D.A.F. Qualidade química e física do solo sob vegetação arbórea nativa e pastagens no Pantanal SulMato-Grossense. Revista Brasileira de Ciência do Solo, v.35, p. 6I3-622, 201 I.

CARNEIRO, M.A.; SOUZA, E.D.; REIS, E.F.; PEREIRA, H.S.; AZEVEDO, W.R. Atributos físicos, químicos e biológicos de solo de Cerrado sob diferentes sistemas de uso e manejo. Revista Brasileira de Ciência do Solo, 33: I47-I57, 2009.

CARVALHO, J.L.N.; CERRI, C.E.P.; CERRI, C.C.; FEIGL, B.J.; PÍCCOLO, M.C.; GODINHO, V.P.; HERPIN, U. Changes of chemical properties in an oxisol after clearing of native Cerrado vegetation for agricultural use in Vilhena, Rondonia State, Brazil. Soil and Tillage Research, v.96, p. 95-102, 2007.

CASTRO, A.P.; QUIRINO, B.F; PAPPAS JR., G.; KUROKAWA, A.S.; NETO, E.L.; KRUGER, R.H. Diversity of soil fungal communities of Cerrado and its closely surrounding agriculture fields. Archives of Microbiology, v.190, n.2, p. 29-139, 2008.

CENCIANI, K.; MAZZETTO, A.M.; LAMMEL, D.R.; FRACETTO, F.J.; FRACETTO, G.G.; FRAZÃO, L.; CERRI, C.C.; FEIGL, B. Genetic and functional diversities of microbial communities in Amazonia soils under different land uses and cultivation. IN: MATOVIC, D. (ed.). Biomass- Detection, production and usage. INTECH, Rijeka, Croatia, p. I25-I46, 20 I I.

CHEN, S.; ZOU, J.; HU, Z.; CHEN, H.; LU, Y. Global annual soil respiration in relation to climate, soil properties and vegetation characteristics: Summary of available data. Agricultural in Forest Meteorology, v.198-199, p.335-346, 2014.

CHERUBIN, M.R.; FRANCO, A.L.C.; CERRI, C.E.P.; OLIVEIRA, D.M.S.; DAVIES, C.A.; CERRI, C.C. Sugarcane expansion in Brazilian tropical soils-Effects of land use change on soil chemical attributes. Agriculture, Ecosystems \& Environment, v. 21I, p.173-184, 2015.
CRECCHIO, C.; CURCI, M.; PELLEGRINO, A.; RICCIUTI, P.; TURSI, N.; RUGGIERO, P. Soil microbial dynamics and genetic diversity in soil under monoculture wheat grown in different long-term management systems. Soil Biology and Biochemistry, v. 39, p. I391-I400, 2007.

CUNHA, E. STONE, L.F. FERREIRA, E.P.B. DIDONET, A.D. MOREIRA, J.A.A. Atributos físicos, químicos e biológicos de solo sob produção orgânica impactada por sistemas de cultivo. Revista Brasileira de Engenharia Agrícola e Ambiental, v. I6, n.I, p. 56-63, 2012.

EFFGEN, E.M.; NAPPO; M.E.; CECÍLIO, R.A.; MENDONÇA, A.R.; MANZOLE, R.; BORCARTE, M. Atributos químicos de um Latossolo Vermelho-Amarelo distrófico sob cultivo de eucalipto e pastagem no sul do Espírito Santo. Scientia Forestalis, v.40, n.95, p. 375-38I, 2012.

EMBRAPA - Empresa Brasileira De Pesquisa Agropecuária. 1997. Manual de Métodos de Análise de Solo. 2.ed. Rio de Janeiro, Ministério da Agricultura e do Abastecimento, 212p.

EVANS, C. D.; JONES, T. G.; BURDEN, A.; OSTLE, N.; ZIELINSKI, P.; COOPER, M. D.A.; PEACOCK, M.; CLARK, J. M.; OULEHLE, F.; COOPER, D.; FREEMAN, C. Acidity controls on dissolved organic carbon mobility in organic soils. Global Chance Biology, v. I8, n. II, p. 33I7-333I, 2012.

FAO -Food and Agriculture Organization of the United Nations. 2005. Creating drought-resistant soil. IN: The importance of soil organic matter - Key to droughtresistant soil and sustained food production, 80, $95 \mathrm{p}$. IN: http://www.fao.org/docrep/009/a0 I00e/a0I00e.pdf Access in: 01/02/2016.

FRANCHINI, J.C., CRISPINO, C.C., SOUZA, R.A., TORRES, E., HUNGRIA, M. Microbiological parameters as indicators of soil quality under various tillage and crop-rotation systems in southern Brazil. Soil \& Tillage Research. V.92, p. 18-29, 2007.

FRAZÃO, L.A.; PICCOLO, M.C.; FEIGL, B.J.; CERRI, C.C.; CERRI, C.E.P. Inorganic nitrogen, microbial biomass and microbial activity of a sandy Brazilian Cerrado soil under different land uses. Agriculture, Ecosystems \& Environment, v.135, p I6I-167, 2010.

GAMA-RODRIGUES, E.F. Biomassa microbiana e ciclagem de nutrientes. In: Santos, G.A. \& Camargo, F.A.O. Fundamentos da matéria orgânica do solo, Porto Alegre, 1999, p. 227-243.

GAMA-RODRIGUES, E.F; GAMA-RODRIGUES, A.C.; PAULINO, G.M.; FRANCO, A.A. Atributos químicos e microbianos de solos sob diferentes coberturas vegetais no norte do Estado do Rio de Janeiro. Revista Brasileira de Ciência do Solo, v.32, p. I52I-I530, 2008a.

GAMA-RODRIGUES, E.F.; BARROS, N.F.; VIANA, A.P.; SANTOS, G. A. Alterações na biomassa e na atividade microbiana da serapilheira e do solo, em decorrência da substituição de cobertura florestal nativa por plantações de eucalipto, em diferentes sítios da Região Sudeste do Brasil. Revista Brasileira de Ciência do Solo, v.32, p.I489I499, 2008b. 
GARCÍA-ORENES, F.; MORUGÁN-CORONADO, A.; ZORNOZA, R.; SCOW, K. Changes in soil microbial community structure influenced by agricultural management practices in a Mediterranean agro-ecosystem. Plos One, v.8, n.II, p. I-9, 2013.

GODOY, S.G.; STONE, L.F.; FERREIRA, E.P.B.; COBBUCII, T.; LACERDA, M.C. Atributos físicos, químicos e biológicos do solo impactados por cultivos sucessivos de arroz. Revista Brasileira de Engenharia Agrícola e Ambiental, v. 17, n. I2, p. I278-I285, 2013.

GOMIERO, T.; PIMENTEL, D.; PAOLETTI, M.G. Environmental Impact of Different Agricultural Management Practices: Conventional vs. Organic Agriculture. Critical Reviews in Plant Science, v.30, p. .95-124, 201 I.

HAYNES, R.J. Soil organic matter quality and the size and activity of the microbial biomass: their significance to the quality of agricultural soils. pp 20I-230. In: HUANG Q, HUANG, P.M. VIOLANTE, A. (EDS) Soil mineral-microbeorganic interactions: Theories and applications. Springer, Berlin. ISBN: 978-3-540-77685-7 (Print) 978-3540-77686-4 (Online), 2008.

HOUGHTON, R.A., SKOLE, D.L.; LEFKOWITZ, D.S. I99I. Changes in the landscape of Latin America between $\mathrm{t} 850$ and 1985: II. Net release of CO2 to the atmosphere. Forest Ecology and Management, v.38, p.173-199, 1991.

HUNGRIA, M., FRANCHINI, J.C., BRANDAO-JUNIOR, O., KASCHUK, G., SOUZA, R.A. Soil microbial activity and crop sustainability in a long-term experiment with three soil-tillage and two crop-rotation systems. Applied Soil Ecology. v.42, p.288-296, 2009.

INSAM, H.; DOMSCH, K.H. Relationship between soil organic carbon and microbial biomass on chronosequences of reclamation sites. Microbial Ecology, v. I5, p. 177-188, 1988.

JENKINSON, D.S.; POWLSON, D.S. The effects of biocidal treatments on metabolism in soil. V. A method for measuring soil biomass. Soil Biology and Biochemistry, v.8, n.3, p. 209-213, 1976.

JIANG, J. P., XIONG, Y. C., JIANG, H. M., YE, D. Y., SONG, Y. J.; LI, F. M. Soil microbial activity during secondary vegetation succession in semiarid abandoned lands of Loess Plateau. Pedosphere. v.19, n.6, p. 735-747, 2009.

KARLEN, D.L.; DITZLER, C.A.; ANDREWS, S.S. Soil quality: Why and how? Geoderma, v. I I4, p. I45- I 56, 2003.

KASCHUK, G., ALBERTON, O., HUNGRIA, M. Three decades of soil microbial biomass studies in Brazilian ecosystems: lessons learned about soil quality and indications for improving sustainability. Soil Biology and Biochemistry, v.42, p.I-I3, 2010.
KONIG, S.; WUBET, T.; DORMANN, C.F.; HEMPEL, S.; RENKER, C.; BUSCOT, F. TaqMan Real-Time PCR Assays To Assess Arbuscular Mycorrhizal Responses to Field Manipulation of Grassland Biodiversity: Effects of Soil Characteristics, Plant Species Richness, and Functional Traits. Applied and Environmental Microbiology, v.76, n. I2, p.3765-3775, 2010 .

KUZYAKOV, Y. Priming effects: Interactions between living and dead organic matter. Soil Biology and Biochemistry, v.42, n. 9, p. I363-I37I, 2010.

LAMMEL, D.R.; NÜSSLEIN, K.; TSAI, S.M.; CERRI, C.C. Land use, soil and litter chemistry drive bacterial community structures in samples of the rainforest and Cerrado (Brazilian Savannah) biomes in Southern Amazonia. European Journal of Soil Biology, v.66, p. 32-39, 2015.

LISBOA, F.J.C.; CHAER, G.M.; JESUS, E.C.; FARIA, S.M.; GONÇALVES, F.S.; SANTOS, F.M.; CASTILHO, A.F.; BERBARA, R.L.L. The influence of litter quality on the relationship between vegetation and below-ground compartments: a Procrustean approach. Plant Soil, v.367, p.55I-562, 2013.

LORENZI, H. Árvores brasileiras: Manual de Identificação e Cultivo de Plantas Arbóreas Nativas do Brasil. Vol. I. Nova Odessa, Ed. Plantarum, 1992. 384p.

LORENZI, H. Árvores brasileiras: Manual de Identificação e Cultivo de Plantas Arbóreas Nativas do Brasil. Vol. 2. Nova Odessa, Ed. Plantarum, 1998. 352p.

LORENZI, H. Árvores brasileiras: Manual de Identificação e Cultivo de Plantas Arbóreas Nativas do Brasil. Vol. 3. Nova Odessa, Ed. Plantarum, 2009. 384p.

LIU, S. L. ET AL. D. Effects of reforestation and deforestation on soil properties in humid mountainous areas: a case study in Wolong Nature Reserve, Sichuan province, China. Soil Use and Management, v. 18, n.4, 376-380, 2002.

LOURENTE, E.R.P.; MERCANTE, F.M.; ALOVISI, A.M.T.; GOMES, C.F;; GASPARINI, A.S.; NUNES, C.M. Atributos microbiológicos, químicos e físicos de solo sob diferentes sistemas de manejo e condições de Cerrado. Pesquisa Agropecuária Tropical, v.44, n. I, p. 20-28, 201 I.

MASSENSSINI, A.M.; BONDUKI, V.H.A.; MELO, C.A.D.; TÓTOLA, M.R.; FERREIRA, F.A.; COSTA, M.D. Soil microorganisms and their role in the interactions between weeds and crops. Planta Daninha, v.32, n.4, p. 8733-884, 2014.

NAZIR, R.; WARMINK, J.A.; BOERSMA, H.; ELSAS, J.D. Mechanisms that promote bacterial fitness in fungalaffected soil microhabitats. FEMS Microbiology Ecology, v.7, n.I, p.169-185, 2010.

OKSANEN, J.; KINDT, R.; LEGENDRE, P.; O'HARA, B. Community ecology package: Vegan. Version I.8.I. 2006. Disponível em: http://cc.oulu. fi/ jarioksa/. Access: 9 out. 2010. 
PANIZZON, J.P.; PILZ JÚNIOR, H.L.; KNAAK, N.; RAMOS, R.C.; ZIEGLER, D.R.; FIUZA, L.M. Microbial diversity: relevance and relationship between environmental conservation and human health. Brazilian Archives of Biology and Technology, v.58, n. I, p. I37-I45, 2015.

PAVAN, M.A.; CHAVES, J.C.D.; SIQUEIRA, R.; ANDROCIOLI FILHO, A.; COLOZZI FILHO, A.; BALOTA, E. L. High coffee population density to improve fertility of an Oxisol. Pesquisa Agropecuária Brasileira, v.34, n.3, p. 459-465, 1999.

POUYU-ROJAS, E.; SIQUEIRA, J.O.; SANTOS, J.G.D. Compatibilidade simbólico de fungos micorrízicos arbusculares com espécies arbóreas tropicais. Revista Brasileira de Ciência do Solo, v.30, p.4I3-424, 2006.

R DEVELOPMENT CORE TEAM. R: a language and environment for statistical computing. Vienna: $R$ Foundation for Statistical Computing, 2012, 409p.

RACHID, C.T.C.C.; PICCOLO, M.C.; LEITE, D.C.A.; BALIEIRO, F.C.; COUTINHO, H.L.C.; ELSAS, J.D.V.; PEIXOTO, R.C.; ROSADO, A. Physical-chemical and microbiological changes in Cerrado Soil under differing sugarcane harvest management systems. BMC Microbiology, v. I2, p. I70, 2012

RACHID, C.T.C.C.; SANTOS, A.L.; PICCOLO, M.C; BALIEIRO, F.C.; COUTINHO; PEIXOTO, R.C.; TIEDJE, J.M.; ROSADO, A.S. Effect of sugarcane burning or Green harvest methods on the Brazilian Cerrado soil bacterial community structure. Plos one, POLO, M.G. KOWALJOW, E.; CASTÁN, E.; SAUZET, O.; MAZZARINO, M.J. Persistent effect of organic matter pulse on a Sandy soil of semiarid Patagonia. Biology and Fertility of Soil, v.5 I, n.2, p. 24I-249, 2015.

ROSCOE, R.; MERCANTE, F.M.; MENDES, I.C.; REIS JUNIOR, F.B.; SANTOS, J.C.F.; HUNGRIA, M. Biomassa microbiana do solo: Fração mais ativa da matéria orgânica. IN: ROSCOE, R. Dinâmica da matéria orgânica do solo em sistemas conservacionistas: Modelagem matemática e métodos auxiliares. Embrapa Agropecuária Oeste, Dourados, 2006. 304 p.

RUÍZ, E.C.; RUIZ, A.C.; VACA, R.; AGUILA, P.D.; LUGO, P. Assessment of soil parameters related with soil quality in agricultural systems. Life Science Journal, v.I2, n.I, p. I54-I67, 2015.

SÁ, J. C. M.; CERRI, C. C.; DICK, A. W.; LAL, R.; VENZKE FILHO, S. P.; PICCOLO, M. C.; FEIGL, B. J. Organic matter dynamics and carbon sequestration rates for a tillage chronosequence in a Brazilian oxisol. Soil Science Society of America Journal, v.65, n.5, p. |486- |499, 200 I.

SANTOS, C.A.; KRAWULSKI, C.C.; BINI, D.; FILHO, T.G.; KNOB, A.; MEDINA, C.C.; FILHO, G.A.; NOGUEIRA, M.A. Reclamation status of a degraded pasture based on soil health indicators. Scientia Agricola, v.72, n.3, p.195-202, 2015.

SCHIMEL, J.; BALSER, T.C.; WALLENSTEIN, M. Microbial stress-response physiology and its implications for ecosystem function. Ecology, v.88, n.6, p. I 386-I 394, 2007.
SCHLOTER, M.; DILLY, O.; MUNCH, J.C. Indicators for evaluating soil quality. Agriculture, Ecosystems \& Environment, v. 98, p. 255-262, 2003.

SILVA, C.F.; PEREIRA, M.G.; MIGUEL, D.L.; FERNANDES, J.C.F.; LOSS, A.; SU, J.Q.; DING, L.J.; YAO, H.Y.; WUENSEN, J.; BAI, S.J.; WEI, W.X.; ZHOU, J.; TIEDJE, J.M.; ZHU, Y.G. Long-term balanced fertilization increases the soil microbial functional diversity in a phosphorus-limited paddy soil. Molecular Ecology, v. 24, n. I, p. I36-I50, 2015.

MENEZES, C.E.G.; SILVA, E.M.R. Carbono orgânico total, biomassa microbiana e atividade enzimática do solo de áreas agrícolas, florestas e pastagens no médio Vale do Paraíba do Sul (RJ). Revista Brasileira de Ciência do Solo, v.36, p. I680-I689, 2012.

SILVA, L.G.; MENDES, I.C.; REIS JR. F.B.; FERNANDES, M.F.; MELO, J.T.; KATO, E. Atributos físicos, químicos e biológicos de um Latossolo de Cerrado em plantio de espécies florestais. Pesquisa Agropecuária Brasileira, v.44, n.6, p.613-620, 2009.

SILVA, M.S.; SALES, A.N.; MAGALHÃES-GUEDES, K,T.; DIAS, D.R.; SCHWAN, R.F.. Brazilian Cerrado Soil Actinobacterial Ecology. BioMed Research International. I- 10, 2013.

SINGH, B.K.; TATE, K.; THOMAS, N.; ROSS, D.; SINGH, J. Differential effect of afforestation on nitrogen-fixing and denitrifying communities and potential implications for nitrogen cycling. Soil Biology and Biochemistry, v.43, 1426|433, 201 I.

SIQUEIRA NETO, M.; PICCOLO, M.C.; SCOPEL, E.; COSTA JUNIOR, C.; CERRI, C.C.; BERNOUX, M. Carbono total e atributos químicos com diferentes usos do solo no Cerrado. Acta Scientiarum Agronomy, v.3I, n.4, p. 709-7I 7, 2009.

SKORUPA, A.L.; GUILHERME, L.R.G.; CURI, N.; SILVA, C.P.C.; SCOLFORO, J.R.S.; MARQUES, J. J. G. S. M. Propriedades de solos sob vegetação nativa em Minas Gerais: Distribuição por fitofisionomia, hidrologia e variabilidade especial. Revista Brasileira de Ciência do Solo, v.36, pl I-22, 2012.

SOUZA, R.A.; TELES, T.S.; MACHADO, W.; HUNGRIA, M.; TAVARES FILHO, J.; GUIMARÃES, M.F. Effects of sugarcane harvesting with burning on the chemical and microbiological properties of the soil. Agriculture, Ecosystems and Environment, v. 155, p. I-6, 2012.

SOUZA, R.F; BRASIL, E.P.F; FIGUEIREDO, C.C.; LEANDRO, W.M. Soil microbial biomass and activity in wetlands located in preserved and disturbed environments in the Cerrado biome. Bioscience Journal, v.3I, n.4, p.I049-I06I, 2015.

STEFANOSKI, D. C.; FIGUEIREDO, C.C.; SANTOS.; MARCHÃO, R.L. Selecting soil quality indicators for different soil management systems in the Brazilian Cerrado. Pesquisa Agropecuária Brasileira, v.5I, n.9, p.1643I65I, 2016. 
SUSYAN, E.A.; WIRTH, S.; ANANYEVA, N.D.; STOLNIKOVA, E.V. Forest succession on abandoned arable soils in European Russia e Impacts on microbial biomass, fungalbacterial ratio, and basal $\mathrm{CO}_{2}$ respiration activity. European Journal of Soil Biology, v.47, p. I69-174, 201 I.

VANCE, E,D,; BROOKES, P.C.; JENKINSON, D.S. As extraction method for measuring soil microbial biomass C. Soil Biology and Biochemistry, 19(6), 703-707, 1987.
WARDLE, D.A.; GHANI, A. A critique of the microbial metabolic quotient $\left(q \mathrm{CO}_{2}\right)$ as a bioindicator of disturbance and ecosystem development. Soil Biology and Biochemistry, v.27, n.12, p. 1601-1610, 1995.

YANG, Y.; JI, C.; MA, W.; WANG, S.; WANG, S.; HAN, W.; MOHAMMAT, A.; ROBINSON, D.; SMITH, P. Significant soil acidification across northern China's grasslands during 1980s-2000s. Global Chance Biology, v.18, p. 2292$2300,2012$. 